\title{
Efektifitas aplikasi Beauveria bassiana sebagai upaya pengendalian wereng batang coklat dan walang sangit pada tanaman padi di Desa Campursari Kecamatan Bulu Kabupaten Temanggung
}

\author{
(The application effectiveness of Beauveria bassiana as an effort to control brown \\ planthoppers and adult rice bugs in rice plants in Campursari Village, Bulu District, \\ Temanggung Regency) \\ T. Purwaningsih, B. A. Kristanto, Karno \\ Agroecotechnology, Faculty of Animal and Agricultural Sciences, Diponegoro University \\ Tembalang Campus, Semarang 50275 - Indonesia \\ Corresponding E-mail: tidhorur@gmail.com
}

\begin{abstract}
Beauveria bassiana is one of the pathogens that can be used as an environmentally friendly bio pesticide, as it does not produce harmful residues and does not cause pest resistance. This research was conducted in the village of Campursari village, District of Bulu, Temanggung Regency. The purpose of this research was to assess the effectiveness of Beauveria bassiana application in order to suppress the population of brown planthopper and adult rice bug in rice plants and to find out rice production. The research used factorial completely randomized design which consisted of two factors. The first factor was the application doses of Beauveria bassiana consisted of 0,100, 150 and $200 \mathrm{~g} / 14 \mathrm{l}$. The second factor was the application interval consisted of 7, 10, and 14 days. The parameters observed were brown planthopper population, adult rice bug population, plant height, number of tillers and grain production. The results showed that application with dose of $200 \mathrm{~g} / 141$ and 7 day interval application was effective to suppress population of brown planthopper and adult rice bug and also saved grain production by 1.20 $\mathrm{kg}$ to $7.02 \mathrm{~kg} / \mathrm{m}^{2}$ depending on application doses.
\end{abstract}

Keywords : planthopper, adult rice bug, Beauveria, doses, application interval.

\begin{abstract}
ABSTRAK
Beauveria bassiana merupakan salah satu patogen yang dapat digunakan sebagai biopestisida yang ramah lingkungan, karena tidak menghasilkan residu yang membahayakan serta tidak menimbulkan resistensi hama. Penelitian ini telah dilakukan di lahan Desa Campursari, Kecamatan Bulu, Kabupaten Temanggung. Tujuan penelitian ini adalah untuk mengkaji efektifitas aplikasi Beauveria bassiana dalam menekan populasi wereng batang coklat maupun walang sangit pada tanaman padi dan untuk mengetahui produksi tanaman padi. Penelitian menggunakan rancangan acak lengkap (RAL) pola faktorial yang terdiri dari 2 faktor. Faktor pertama yaitu dosis Beauveria bassiana terdiri dari 0, 100, 150 dan $200 \mathrm{~g} / 14$ 1. Faktor kedua yaitu interval aplikasi 7, 10, dan 14 hari. Parameter yang diamati yaitu populasi hama wereng batang coklat, populasi walang sangit, tinggi tanaman, jumlah anakan dan produksi gabah. Hasil penelitian menunjukkan bahwa aplikasi dosis $200 \mathrm{~g} / 141$ dengan interval aplikasi 7 hari sekali efektif menekan populasi hama wereng batang coklat dan hama walang sangit serta menyelamatkan produksi gabah sebesar $1,20 \mathrm{~kg} / \mathrm{m}^{2}$ hingga $7,02 \mathrm{~kg} / \mathrm{m}^{2}$ bergantung dosis aplikasi.

Kata kunci : Wereng, walang sangit, Beauveria, dosis, interval aplikasi.
\end{abstract}




\section{PENDAHULUAN}

Tanaman padi merupakan komoditas strategis yang tetap mendapat prioritas penanganan dalam pembangunan pertanian di Indonesia, padi menjadi salah satu sumber karbohidrat yang dikonsumsi sebagian besar penduduk di dunia, dikarenakan padi termasuk jenis tanaman yang menghasilkan bahan pangan. Kandungan gizi yang tinggi menjadikan kebutuhan beras setiap tahun semakin bertambah seiring dengan laju pertumbuhan penduduk, sehingga tanaman padi sebagai salah satu bidang pertanian yang digalakan di wilayah Indonesia. Produksi beras mengalami penurunan, tetapi permintaan konsumsi beras meningkat. Penyebab menurunnya produksi padi diantaranya disebabkan oleh timbulnya serangan hama, diantaranya serangan wereng batang coklat dan walang sangit yang mengakibatkan kerusakan hingga besarnya mencapai $50 \%$ produksi padi setiap panen. Serangan hama wereng batang coklat dan walang sangit, sangat terkait dengan kondisi cuaca. Kondisi cuaca yang tidak stabil merupakan faktor utama munculnya hama tersebut. Wereng batang coklat berkembangbiak dengan baik pada kondisi cuaca panas dan basah. Oleh karenanya, serangan wereng coklat pada musim kemarau basah lebih parah dibanding musim penghujan. Serangan wereng batang coklat sangat berpotensi mengganggu kestabilan produksi padi (Untung, 2007).

Hama walang sangit merupakan hama yang menyerang tanaman padi saat memasuki masa pembungaan hingga masak susu. Walang sangit dapat mengakibatkan bulir gabah tanaman menjadi hampa sampai tidak berbuah kembali (Tulung, 2004). Kehadiran hama perlu dikendalikan, apabila populasinya telah melebihi batas ambang ekonomi. Beberapa teknologi yang dikembangkan untuk mengurangi ketergantungan insektisida kimia antara lain adalah pemanfaatan musuh alami, baik berupa parasitoid, predator dan patogen. Salah satu patogen yang dikembangkan untuk pengendalian wereng batang coklat dan walang sangit adalah cendawan Beauveria bassiana yang dapat digunakan sebagai biopestisida yang ramah lingkungan, karena tidak menghasilkan residu yang membahayakan serta tidak menimbulkan resistensi dan resurjensi hama
(Meidianti et al., 2010). Cendawan endofit memiliki kelebihan di dalam pegendalian hama, diantaranya tidak mengasilkan racun terhadap tanaman, bahkan menghasilkan hormon perangsang tumbuh (Siddiqui dan Shaukat, 2003).

Tujuan penelitian ini yaitu untuk mengkaji efektifitas aplikasi Beauveria bassiana dalam menekan populasi wereng batang coklat maupun walang sangit pada tanaman padi dan untuk mengetahui produksi tanaman padi. Manfaat yang diperoleh antara lain dapat mengetahui efektifitas pada aplikasi Beauveria bassiana dalam menekan populasi wereng batang coklat maupun walang sangit pada tanaman padi.

\section{MATERI DAN METODE}

Penelitian dilaksanakan pada bulan Juli Oktober 2016 di lahan Desa Campursari , Kecamatan Bulu, Kabupaten Temanggung, Jawa Tengah.

\section{Materi}

Bahan yang digunakan yaitu benih padi varietas Ciherang, pupuk kandang, pupuk urea, pupuk ponska, pupuk ZA dan agensia hayati Beauveria bassiana. Peralatan yang digunakan dalam proses penelitian ini antara lain cangkul atau traktor untuk menggali tanah, ajir sebagai cagakan papan nama, blangko untuk pengamatan, papan nama untuk menandai tanaman, alat tulis. Pengamatan dilakukan secara langsung dengan mengamati 10 rumpun pada tiap petak.

\section{Metode}

Penelitian ini diawali dengan pengolahan lahan dan persiapan alat dan bahan, plotting lahan $\pm 1500 \mathrm{~m}^{2}$ dibagi menjadi 48 petak dengan ukuran tiap petak $4 \times 3 \mathrm{~m}^{2}$. Lahan dibajak dengan menggunakan traktor, penyemaian dengan pemilihan benih yang baik varietas ciherang dan dilakukan perendaman. Pupuk kandang sebanyak $168 \mathrm{~kg}$ diberikan setelah pengolahan lahan, dua hari sebelum tanam. Pupuk urea $25 \mathrm{~kg}, 50 \mathrm{~kg}$ pupuk ponska dan ZA sebanyak $10 \mathrm{~kg}$. Pemupukan urea dilakukan sebanyak tiga kali yaitu saat tanam, saat tanaman berumur 2 dan 4 minggu setelah tanam. Penanaman dilakukan 
dengan memindahkan bibit dari tempat penyemaian ke lahan pertanaman untuk didapatkan hasil produk dari tanaman yang dibudidayakan. Pemeliharaan meliputi pengairan dan penyiangan. Pembuatan Beauveria bassiana dilakukan dengan bahan dasar dari jagung. Penentuan populasi hama dilakukan dengan menggunakan metode Gabriel dan Riyanto (2005). Nilai rata-rata, nilai maksimum, nilai minimum dan standar deviasi pada setiap populasi dihitung berdasarkan rumus :

Rerata $=\frac{\sum x}{n}=\frac{x 1+x 2+\ldots+x n}{n}$

Keterangan :

$\mathrm{x}=$ Wakil data

$\mathrm{n}=$ Jumlah data

\section{Rancangan Percobaan dan Analisis data}

Penelitian ini dilaksanakan menggunakan rancangan acak lengkap (RAL) faktorial dengan 4 ulangan. Faktor pertama adalah dosis Beauveria bassiana yaitu 0, 100, 150 dan $200 \mathrm{~g} / 14$ 1. Faktor kedua adalah interval aplikasi Beauveria bassiana yaitu 7, 10 dan 14 hari. Masing-masing unit percobaan diulang 4 kali, sehingga keseluruhan terdapat 48 unit percobaan. Tanaman padi berumur 14 hari setelah tanaman diinfeksi masingmasing 20 ekor wereng batang coklat dan saat padi bulir gabah matang susu diinfeksi 20 ekor walang sangit sesuai dengan perlakuan. Tanaman padi, hama wereng batang coklat dan walang sangit ditempatkan pada kurungan yang terbuat dari potongan besi dan kain kasa dengan desain tidak ada celah lubang besar, selanjutnya disemprot dengan larutan Beauveria bassiana sesuai dengan perlakuan yang diujikan. Parameter yang diamati adalah populasi hama wereng batang coklat pada 10 rumpun tiap petak, populasi hama walang sangit pada 10 rumpun tiap petak dan hasil produksi tanaman. Data tersebut diolah dengan menggunakan anova dan dilanjutkan dengan uji Duncan taraf 5\%.

\section{HASIL DAN PEMBAHASAN}

\section{Populasi Wereng Batang Coklat}

Rerata populasi hama wereng batang coklat dengan pemberian perlakuan dosis dan interval aplikasi yang berbeda disajikan pada Tabel 1 .

Hasil analisis ragam menunjukkan bahwa perlakuan dosis Beauveria bassiana berpengaruh nyata terhadap populasi wereng batang coklat, sedangkan interval aplikasi tidak berpengaruh nyata terhadap populasi wereng batang coklat, serta tidak ada interaksi antara dosis dan interval aplikasi. Uji Duncan menunjukkan bahwa semakin tinggi dosis semakin menurunkan populasi wereng batang coklat secara nyata (Tabel 1). Aplikasi Beauveria bassiana dosis $100 \mathrm{~g} / 141$ secara efektif menurunkan populasi wereng batang coklat. Peningkatan dosis aplikasi semakin menurunkan populasi. Penurunan populasi karena

Tabel 1. Populasi Hama Wereng Batang Coklat yang mendapatkan Aplikasi Beauveria bassiana pada Dosis dan Interval Berbeda

\begin{tabular}{|c|c|c|c|c|c|}
\hline \multirow{2}{*}{$\begin{array}{c}\text { Interval } \\
\text { Aplikasi } \\
\text { (hari) }\end{array}$} & \multicolumn{5}{|c|}{ Dosis Beauveria bassiana (g/14 l) } \\
\hline & 0 & 100 & 150 & 200 & Rerata \\
\hline \multicolumn{6}{|c|}{ - } \\
\hline 7 & 26,43 & 11,48 & 10,14 & 8,05 & 14,03 \\
\hline 10 & 26,06 & 13,23 & 11,23 & 9,05 & 14,89 \\
\hline 14 & 25,11 & 13,95 & 11,27 & 10,02 & 15,09 \\
\hline Rerata & $25,87^{\mathrm{a}}$ & $12,88^{\mathrm{b}}$ & $10,88^{\mathrm{c}}$ & $9,04^{\mathrm{d}}$ & \\
\hline
\end{tabular}

Keterangan : 1. Superskrip berbeda pada baris rerata menunjukkan perbedaan nyata $(\mathrm{P}<0,05)$.

2. Populasi awal hama wereng batang coklat sebanyak 20 ekor. 


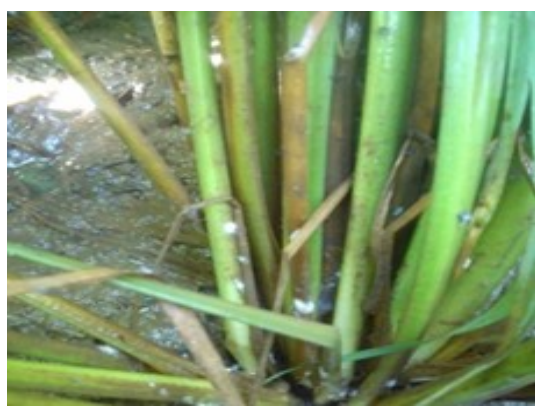

Ilustrasi 1. (a). Wereng batang coklat menyerang rumpun padi

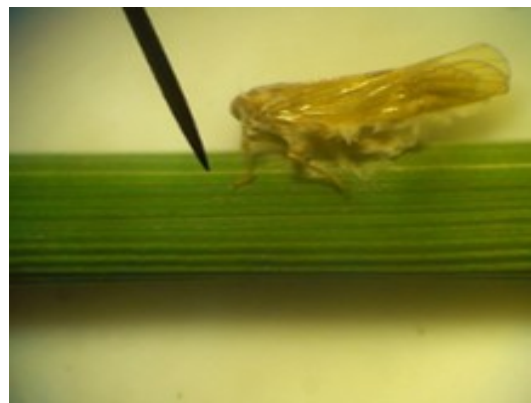

(b). wereng batang coklat yang terinfeksi $B$. bassiana terjadi mortalitas wereng batang coklat akibat aplikasi Beauveria bassiana. Mortalitas semakin besar dengan pemberian dosis Beauveria bassiana sampai $200 \mathrm{~g} / 14$ l. Rerata populasi wereng batang coklat pada perlakuan kontrol, lebih tinggi dibandingkan dengan perlakuan penggunaan dosis aplikasi Beauveria bassiana yang lain. Perbedaan rerata populasi pada masing-masing perlakuan dosis diduga terkait dengan kontak langsung Beauveria bassiana terhadap wereng batang coklat semakin tinggi. Interval aplikasi 7, 10 dan 14 hari tidak berpengaruh nyata terhadap populasi wereng batang coklat. Heriyanto dan Suharno (2008) menyatakan bahwa keberhasilan penggunaan cendawan entomopatogen dalam pengendalian hama antara lain ditentukan oleh kerapatan konidia dan daya kecambah. Semakin tinggi kerapatan konidia dan banyaknya yang berkecambah maka peluang cendawan dalam mematikan serangga juga makin cepat, demikian juga sebaliknya semakin rendah kerapatan konidia dan sedikit yang berkecambah maka peluang cendawan dalam mematikan juga semakin lambat.

\section{Populasi Walang Sangit}

Rerata populasi hama walang sangit dengan pemberian perlakuan dosis dan interval aplikasi yang berbeda disajikan pada Tabel 2 .

Berdasarkan hasil analisis ragam dan uji lanjut duncan, efektifitas aplikasi beauveria bassiana dalam mengendalikan populasi walang sangit tergantung pemberian dosis dan interval aplikasi. Rerata populasi walang sangit pada

Tabel 2. Populasi Hama Walang Sangit yang mendapatkan Aplikasi Beauveria bassiana pada Dosis dan Interval Berbeda

\begin{tabular}{cccccc}
\hline \hline Interval & \multicolumn{5}{c}{ Dosis Beauveria bassiana $(\mathrm{g} / 141)$} \\
\cline { 2 - 6 } Aplikasi (hari) & 0 & 100 & 150 & 200 & Rerata \\
\hline & ------------ & & \\
7 & 26,43 & 12,50 & 10,39 & 6,30 & 13,91 \\
10 & 26,56 & 14,23 & 11,73 & 7,80 & 15,20 \\
14 & 26,85 & 15,70 & 13,02 & 9,52 & 16,27 \\
\hline Rerata & $26,62^{\mathrm{a}}$ & $14,14^{\mathrm{b}}$ & $11,71^{\mathrm{c}}$ & $7,87^{\mathrm{d}}$ \\
\hline
\end{tabular}

Keterangan : 1. Superskrip berbeda pada baris rerata menunjukkan perbedaan nyata $(\mathrm{P}<0,05)$.

2. Populasi awal hama walang sangit sebanyak 20 ekor. 


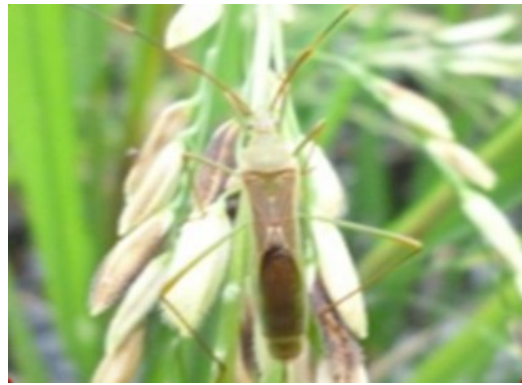

Ilustrasi 2. (a).Walang sangit menghisap bulir padi

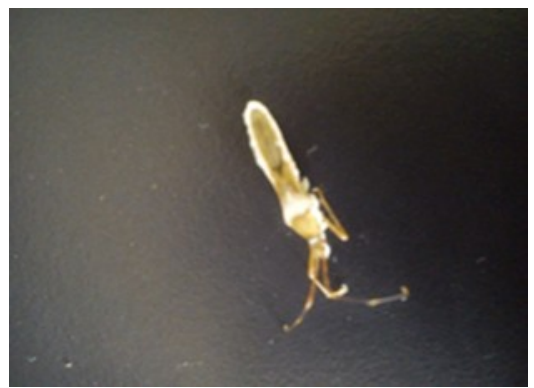

(b). Walang sangit terinfeksi Beauveria bassiana perlakuan kontrol (26,62 ekor), lebih tinggi dibandingkan dengan perlakuan penggunaan dosis aplikasi yang lain (14,14 ekor) $100 \mathrm{~g} / 14$ 1, (11,71 ekor) $150 \mathrm{~g} / 141 \mathrm{dan}(7,87$ ekor) $200 \mathrm{~g} / 141$. Perbedaan rerata populasi pada masing-masing perlakuan dosis diduga disebabkan oleh lama dan pendeknya interval aplikasi. Semakin tinggi dosis yang diberikan maka akan semakin besar dalam menekan populasi hama walang sangit. Hasil penelitian Hasyim (2006) bahwa semakin tinggi dosis Beauveria bassiana yang diaplikasikan akan semakin banyak konidia yang kontak pada tubuh larva, sehingga mengakibatkan tingkat mortalitas yang lebih banyak. Menurut Wahyono (2013), bahwa tingkat kematian $N$. lugens baru terlihat pada hari ke 6 dan ke 7 hari setelah aplikasi, terutama pada cendawan $B$. bassiana strain Lophobaris sp. Interval aplikasi 7, 10 dan 14 hari sekali tidak berpengaruh nyata dalam menekan populasi walang sangit.

\section{Produksi Gabah}

Berdasarkan hasil analisis ragam dan uji lanjut duncan, efektifitas aplikasi beauveria bassiana pada produksi gabah, bergantung pemberian dosis dan interval aplikasi dan terdapat interaksi antara keduanya. Berat gabah kering panen, baik pada aplikasi dosis $100(6,27 \mathrm{~kg}), 150$ $(6,42 \mathrm{~kg})$ dan $200 \mathrm{~g} / 141(7,16 \mathrm{~kg})$ dengan interval aplikasi 14 hari sekali hasilnya lebih tinggi dari pada perlakuan dosis $0 \mathrm{~g} / 141(5,07 \mathrm{~kg})$. Efektifitas beauveria bassiana baik dosis aplikasi 100, 150 dan $200 \mathrm{~g} / 141$ meningkat dengan semakin pendek interval aplikasi. Produksi gabah dapat dilihat pada Tabel 3.

Aplikasi Beauveria bassiana dosis $100 \mathrm{~g} / 14$ 1 secara efektif telah menyebabkan mortalitas walang sangit, mortalitas semakin besar dengan pemberian sampai dengan dosis $200 \mathrm{~g} / 141$. Hal ini terkait dengan kontak langsung Beauveria bassiana terhadap walang sangit semakin banyak.

Tabel 3. Produksi Gabah

\begin{tabular}{cccccc}
\hline \hline \multirow{2}{*}{$\begin{array}{c}\text { Interval Aplikasi } \\
\text { (hari) }\end{array}$} & 0 & \multicolumn{5}{c}{ Dosis Beauveria bassiana $(\mathrm{g} / 14 \mathrm{l})$} \\
\cline { 2 - 6 } & ---00 & 150 & 200 & Rerata \\
\hline 7 & $5,12 \mathrm{hi}$ & $9,59 \mathrm{e}$ & $10,52 \mathrm{c}$ & $12,14 \mathrm{a}$ & $9,34 \mathrm{a}$ \\
10 & $5,10 \mathrm{i}$ & $8,82 \mathrm{f}$ & $9,71 \mathrm{~d}$ & $11,44 \mathrm{~b}$ & $8,77 \mathrm{~b}$ \\
14 & $5,07 \mathrm{i}$ & $6,27 \mathrm{gh}$ & $6,42 \mathrm{~g}$ & $7,16 \mathrm{f}$ & $6,23 \mathrm{c}$ \\
\hline Rerata & $5,10 \mathrm{~d}$ & $8,23 \mathrm{c}$ & $8,88 \mathrm{~b}$ & $10,25 \mathrm{a}$ \\
\hline
\end{tabular}

Superskrip berbeda pada kolom dan baris rerata menunjukkan perbedaan nyata $(\mathrm{P}<0,05)$.

Superskrip berbeda pada matrik interaksi menunjukkan perbedaan nyata $(\mathrm{P}<0,05)$. 
Aplikasi Beauveria bassiana menyebabkan mortalitas hama wereng batang coklat dan walang sangit sehingga menurunkan populasi wereng batang coklat dan walang sangit. Penurunan populasi hama akan menurunkan serangan pada tanaman padi. Serangan hama wereng batang coklat menyebabkan gangguan fisiologi tanaman padi yang berdampak pada penurunan tinggi tanaman dan menghisap cairan batang padi yang menyebabkan kematian anakan padi sehingga menurunkan jumlah anakan produktif dengan keragaan yang lebih pendek. Gangguan pertumbuhan dan kematian anakan padi berakibat padan penurunan hasil gabah. Serangan hama walang sangit terjadi pada saat tanaman padi berbunga hingga bulir gabah masak susu. Hama walang sangit menyerang dengan menghisap cairan dalam bulir gabah yang masak susu dalam berakibat bulir gabah menjadi hampa. Menurut Tulung (2004), bahwa hama walang sangit menyerang tanaman padi pada fase mulai keluarnya malai sampai fase bulir gabah masak susu. Semakin tinggi populasi hama walang sangit akan semakin banyak bulir gabah yang hampa sehingga berdampak pada penurunan hasil gabah yang semakin besar.

Aplikasi Beauveria bassiana secara efektif menurunkan populasi hama wereng batang coklat dan walang sangit, sehingga menurunkan serangan dan menurunkan kehilangan hasil gabah. Efektivitas Beauveria bassiana mengendalikan hama wereng batang coklat lebih tinggi dibanding walang sangit. Hama wereng batang coklat menyerang dan hidup menggerombol di rumpun padi, sehingga Beauveria bassiana mudah menginfeksi wereng batang coklat, dan perilaku hidup yang menggerombol lebih memudahkan dan mempercepat penularan atau menginfeksi ke individu yang lain. Hama walang sangit setelah menghisap cairan bulir gabah, tidak menetap di malai padi, dan tidak hidup secara menggerombol sehingga infeksi Beauveria bassiana lebih sedikit dan lebih lama. Menurut Sudarmo (2001), bahwa walang sangit dan tidak hidup tidak hanya menyerang dan hidup di malai tanaman padi, tetapi juga memiliki inang alternatif berupa rumput disekitar pertanaman padi untuk hidup dan melangsungkan perkembangbiakan.

Petak yang tidak diaplikasi Beauveria bassiana sebagai perlakuan kontrol, mengalami serangan hama wereng batang coklat dan walang sangit paling berat, karena tidak ada pengendalian secara hayati. Oleh karenanya, petak perlakuan kontrol mempunyai jumlah anakan produktif paling sedikit dengan keragaan paling pendek yang berdampak pada kehilangan hasil gabah paling besar atau produksi gabah paling sedikit. Serangan hama wereng batang coklat dan walang sangit menyebabkan penurunan hasil gabah. Aplikasi Beauveria bassiana mampu menurunkan populasi dan tingkat serangan hama, sehingga mampu memperkecil hasil gabah yang hilang akibat serangan hama. Hasil gabah yang dapat diselamatkan oleh Beauveria bassiana semakin besar dengan meningkatnya dosis dan interval aplikasi.

\section{KESIMPULAN}

Aplikasi Beauveria bassiana dosis $100 \mathrm{~g} / 141$ dengan interval 14 hari sekali efektif menekan atau mengendalikan populasi hama wereng batang coklat dan hama walang sangit. Efektivitas Beauveria bassiana semakin besar dengan meningkatnya dosis dan semakin pendeknya interval aplikasi. Efektifitas beauveria bassiana untuk mengendalikan hama wereng batang coklat lebih tinggi dibandingkan hama walang sangit. Aplikasi Beauveria bassiana dapat menyelamatkan hasil gabah berkisar antara 1,20 sampai $4,47 \mathrm{~kg} / \mathrm{m}^{2}$ untuk dosis $100 \mathrm{~g} / 14 \mathrm{l}, 1,35$ sampai $5,40 \mathrm{~kg} / \mathrm{m}^{2}$ untuk dosis $150 \mathrm{~g} / 141$ dan 2,09 sampai $7,02 \mathrm{~kg} / \mathrm{m}^{2}$ untuk dosis $200 \mathrm{~g} / 14 \quad 1$ bergantung interval aplikasi.

\section{DAFTAR PUSTAKA}

Cheng, J. A. and J. Holt. 2000. A Systems Analysis Approach to Brown Planthopper Control on Rice in Zhejiang Province, China. I. Simulation of outbreaks. Journal of Applied Ecology. 27, 85 - 99.

Hasyim A. 2006. Cara Mudah Mendapatkan Jamur Entomopatogen Beauveria bassiana dari Tanah dengan Teknik Umpan Serangga. Diakses pada tanggal 18 Maret 2011.

Heriyanto dan Suharno. 2008. Studi Patogenitas Metarhizium anisopliae (Meth.) Sor Hasil 
Perbanyakan Medium Cair Alami Terhadap Larva Oryctes rhinoceros. J. Ilmu-ilmu Pertanian 4 (1): 47-54.

Meidianti, S., N.A. Muanis dan A. Raharjo. 2010. Membuat Pestisida Organik. PT. Media Agromedia Pustaka. Jakarta.

Sudarmo, S. 2001. Pengendalian Serangga, Hama, Penyakit dan Gulma Pada Padi. Penerbit Kanisius Yogyakarta.

Siddiqui, I. A. \& S. S. Shaukat. 2003, Endophytic bacteria : Prospect and opportunities for the biological control of plant-parasitic nematodes, Nematol. Medit. $31: 111-120$

Tulung, M. 2004. Sistem Peramalan Hama. Fakultas Pertanian UNSRAT Manado.

Untung K. 2007. Pembangunan Berkelanjutan Berwawasan Lingkungan. Program Pasca Sarjana Fakultas Pertanian. Universitas Gadjah Mada. Yogyakarta.

Wahyono, T. E. 2013. Tehnik pengujian patogenisitas beberapa strain jamur Beauveria bassiana terhadap wereng batang coklat (Nilaparvata lugens). Buletin Teknik Pertanian 18 (1): 36-39. 